\title{
PEMBENTUKAN PORTOFOLIO OPTIMAL DENGAN MENGGUNAKAN MODEL INDEKS TUNGGAL
}

\author{
Irvan Fendy Prasetyo ${ }^{1}$ \\ Anak Agung Gede Suarjaya ${ }^{2}$ \\ ${ }^{1,2}$ Fakultas Ekonomi dan Bisnis Universitas Udayana (Unud), Bali, Indonesia \\ email: irvan.f.p@gmail.com
}

\begin{abstract}
ABSTRAK
Tujuan penelitian ini adalah untuk mengetahui saham-saham dari anggota Indeks Kompas 100 yang dapat membentuk portofolio optimal dan untuk mengetahui proporsi masingmasing saham terpilih serta tingkat return dan risiko dari portofolio yang dihasilkan. Metode yang digunakan adalah dengan menggunakan pendekatan Model Indeks Tunggal dengan teknik analisis deskriptif. Data dalam penelitian ini adalah data sekunder yang diperoleh dari BEI, Yahoo Finance, dan BI. Populasi dalam penelitian ini berjumlah 77 saham. Jumlah sampel yang diambil sebanyak 65 saham perusahaan dari Indeks Kompas 100, dengan metode slovin. Berdasarkan hasil analisis didapat dari 65 saham anggota Indeks Kompas 100 diperoleh kombinasi sebanyak 20 saham yang dapat membentuk portofolio optimal yaitu BUMI, MAPI, INCO, DOID, INDY, CPIN, BKSL, ACES, MEDC, ITM, UNTR, TINS, BDMN, JPFA, BBCA, BJBR, PNBN, TARA, PBRX dan ANTM dengan tingkat keuntungan (expected return) portofolio sebesar 3.20 persen dengan risiko sebesar 0.11 persen.

Kata kunci : Indeks Kompas 100, Model Indeks Tunggal, Portofolio Optimal.
\end{abstract}

\begin{abstract}
The purpose of this study is to determine the stocks of the Kompas 100 Index that can form optimal portfolios and to find out the proportions of each selected stock and the level of return and risk of the resulting portfolio. Single Index Model with descriptive analysis was used. The data was obtained from the IDX, Yahoo Finance, and BI. The population in this study amounted to 77 shares. The number of samples taken was 65 company shares from the Kompas 100 Index, using the Slovin method. Based on the results of the analysis obtained from 65 shares of Kompas 100 members obtained a combination of 20 shares that can form an optimal portfolio of BUMI, MAPI, INCO, DOID, INDY, CPIN, BKSL, ACES, MEDC, ITM, UNTR, TINS, BDMN, JPFA, BBCA, BJBR, PNBN, TARA, PBRX and ANTM with portfolio expected return of 3.20 percent with a risk of 0.11 percent.

Keywords: Compass 100 Index, Single Index Model, Optimal Portfolio
\end{abstract}




\section{PENDAHULUAN}

Investasi merupakan suatu kegiatan yang sangat erat kaitannya dalam dunia bisnis. Setiap bisnis memerlukan investasi untuk kelangsungan hidupnya. Investasi dapat didefinisikan sebagai penundaan konsumsi sekarang untuk dimasukan ke aktiva produktif selama periode waktu tertentu dan untuk digunakan di masa yang akan datang. Penundaan konsumsi sekarang untuk diinvestasikan ke aktiva yang produktif akan meningkatkan utility total (Kozłowska, 2015)

Saat ini semakin beragam pililhan investasi bagi masyarakat, salah satunya adalah investasi di pasar modal. Masyarakat sebagai pemilik dana semakin sadar dengan adanya alternatif investasi yang cukup menarik dalam mendatangkan return, yaitu investasi pada saham selain investasi real, deposito maupun tabungan. Kemajuan di bidang teknologi dan informasi yang pesat merupakan faktor yang mendorong meningkatnya kesadaran masyarakat tersebut, sehingga masyarakat akan lebih mudah dalam memperoleh dan menyalurkan dana di pasar modal (Sushko \& Turner, 2018)

Faktor yang mendukung kepercayaan pemodal terhadap pasar modal adalah persepsi mereka akan kewajaran harga sekuritas (saham). Dalam keadaan seperti itu, pasar modal dikatakan efisien secara informasional. Pasar modal dikatakan efisiensi secara informasional apabila harga sekuritassekuritasnya mencerminkan semua informasi yang relevan. Oleh karena itu informasi yang tidak benar dan tidak tepat tentunya akan menyesatkan para pemodal dalam melakukan investasi pada sekuritas, sehingga ini akan merugikan para pemodal. Semakin tepat dan cepat informasi sampai kepada calon pemodal dan dicerminkan pada harga saham, maka pasar modal yang bersangkutan semakin efisien (Masry, 2017)

Pasar modal adalah pertemuan antara pihak yang memiliki kelebihan dana dengan pihak yang membutuhkan dana dengan cara memperjualbelikan sekuritas (Sanrego, 2017). Investor sebagai pihak yang memiliki kelebihan dana dapat menginvestasikan dananya pada berbagai sekuritas dengan harapan memperoleh return di pasar modal tersebut. Berbeda halnya dengan perusahaan. Perusahaan sebagai pihak yang memerlukan dana dapat memanfaatkan dana tersebut untuk mengembangkan proyek-proyeknya (Lerskullawat, 2017).

Investasi khususnya pada efek (surat berharga), tentunya investor harus berfikir rasional dalam menghadapi perdagangan di pasar modal. Harga saham di bursa efek akan ditentukan oleh kekuatan permintaan dan penawaran. Pada saat permintaan saham meningkat, maka harga saham tersebut akan cenderung meningkat. Sebaliknya, pada saat banyak orang menjual saham, maka harga saham tersebut cenderung akan mengalami penurunan (Bosch-Badia et al., 2018)

Tujuan utama seorang investor melakukan investasi adalah untuk mendapatkan return. Return merupakan hasil yang diperoleh dari investasi (Abramov et al., 2015). Dalam konteks manajemen investasi, terdapat return harapan dan return aktual. Investor yang menginvestasikan dananya akan mensyaratkan tingkat return tertentu dan jika periode investasi telah berlalu, 
investor akan dihadapkan pada tingkat return sesungguhnya diterima. Perbedaan return harapan dengan return yang benar-benar diterima merupakan risiko yang harus selalu dipertimbangkan dalam proses investasi.

Setiap keputusan investasi selalu mengandung suatu risiko. Tingkat return dengan risiko sangat berkaitan erat satu sama lainnya. Semakin tinggi risiko semakin tinggi pula return yang diharapkan. Tingkat ekspektasi return tinggi maka risiko yang dihadapi oleh investor dalam berinvestasi pada suatu saham juga akan semakin tinggi, begitu pula sebaliknya, apabila tingkat ekspektasi return rendah, maka risiko yang akan dihadapi investor juga akan rendah dan dapat di diversifikasi (Yin, 2019)

Portofolio menjadi salah satu saran terbaik bagi investor yang ingin memperkecil atau mendiversifikasikan risiko. Keberadaan portofolio menyebabkan investor berpotensi memeroleh keuntungan (return) yang lebih besar dibandingkan dengan risiko yang diperoleh di masa datang. Pembentukan portofolio merupakan suatu penanaman modal berupa kombinasi dari beberapa surat yang dilakukan pada beberapa kelas asset sehingga memperoleh return atau pengembalian yang optimal dengan risiko yang seminimal mungkin (Meman, 2015). Teori portofolio adalah bagimana melakukan pemilihan portofolio dari sekian banyak aset, untuk memaksimalkan return harapan pada tingkat risiko tertentu yang bersedia ditanggung investor.Tujuan membentukan suatu portofolio saham adalah untuk mendapatkan return ekspektasi yang maksimal dengan tingkat risiko tertentu atau mendapatkan return ekspetasi tertentu dengan risiko yang minimal (Darmitha \& Purbawangsa, 2016).

Melakukan investasi dengan mengkombinasikan beberapa saham meyebabkan investor dapat memperoleh return yang optimal dan dapat memperkecil risiko, karena risiko yang ada tersebar ke beberapa saham dan tidak hanya di satu saham saja, sehingga risiko yang ditanggung investor tidak terlalu berat. Investor yang memiliki pemikiran yang logis akan memilih berinvestasi dengan membentuk sebuah portofolio, hal tersebut dikarenakan portofolio yang akan dibentuk investor bergantung pada fungsi utilitas dari masing-masing saham, sehingga nantinya portofolio yang akan dibentuk merupakan portofolio yang sesuai dengan preferensi investor terhadap return dan risiko yang akan dihadapi (Farias et al., 2014).

Pembentukan suatu portofolio dapat menggunakan beberapa model pendekatan portofolio, yaitu Model Indeks Tunggal serta Model Markowitz. Model Markowitz dalam analisisnya terbatas, hanya dapat dilakukan pada portofolio yang terdiri dari aset yang berisiko saja. Model Markowitz memang membantu untuk menghitung return harapan dan risiko portofolio, tetapi model ini memerlukan perhitungan kovarians yang terlalu kompleks jika dihadapkan pada banyaknya sekuritas (Mary \& Rathika, 2015). Portofolio Model Markowitz yang begitu kompleks dalam perhitungan kovarians selanjutnya dikembangkan oleh William Sharpe dengan menciptakan Model Indeks Tunggal. Kesederhanaan dari perhitungan dalam Model Indeks Tunggal inilah yang kemudian menjadi sebab invetor lebih sering 
mengguunakan model ini dibandingkan dengan Model Markowitz (Mandal, 2014).

Para investor biasanya lebih banyak menggunakan Model Indeks Tunggal dalam membentuk sebuah portofolio optimal, karena model ini dianggap lebih mudah dan merupakan penyederhanaan dari Model Markowitz. Model Indeks Tunggal ini juga membutuhkan perhitungan yang lebih sedikit dan sangat memperhatikan keadaan pasar dari return dan risiko yang diharapkan (Ariasih \& Mustanda, 2018)

Teori Markowitz didasari beberapa karakteristik: (1) periode investasi tunggal misalnya satu tahun, (2) tidak ada biaya transaksi, (3) preferensi investor hanya berdasar pada return harapan dan risiko, (4) belum memperhitungkan kemungkinan investor untuk melakukan investasi pada aset bebas risiko, dan (5) perhitungannya kompleks dan rumit. Karakteristik tersebut tidak dijumpai dalam Model Indeks Tunggal. Model Indeks Tunggal memiliki karakteristik yang menghubungkan perhitungan return setiap aset pada return indeks pasar, Asumsi yang dipakai dalam model ini adalah bahwa sekuritas akan berkorelasi hanya jika sekuritas-sekuritas tersebut mempunyai respon yang sama terhadap perubahan pasar. Model ini dapat menyederhanakan model perhitungan Markowitz yang kompleks. Berdasarkan karakteristik tersebut bahwa dibandingkan dengan Model Markowitz, Model Indeks Tunggal lebih sederhana serta mempertimbangkan aspek pasar dan aspek keunikan perusahaan, oleh sebab Model Indeks Tunggal dipilih sebagai metode dalam penelitian ini.

Model Indeks Tunggal juga menunjukkan adanya hubungan antara sekuritas dengan perubahan harga pasar. Hal tersebut dapat dilihat ketika kondisi pasar yang ditunjukkan oleh indeks pasar membaik maka nilai harga sahamnya akan meningkat, begitu pula sebaliknya apabila kondisi pasar saat itu memburuk maka nilai harga saham juga akan menurun. Portofolio optimal dengan menggunakan Model Indeks Tunggal ini didasarkan pada sebuah angka yang dapat menunjukan apakah bsuatu sekuritas dapat dimasukkan ke dalam portofolio optimal atau tidak. Angka tersebut adalah hasil dari perhitungan Excess Return to Beta $(E R B)$ yang merupakan selisih return ekspektasi dengan return aktiva bebas risiko. Model Indeks Tunggal juga memerlukan sebuah titik pembatas (cut-off point) untuk memisahkan saham mana saja yang akan dimasukkan ke dalam portofolio optimal (Ramadhan et al., 2014). Mengetahui saham-saham apa saja yang bisa membentuk portofolio dapat dilakukan dengan cara membandingkan antara nilai cut-off point $(\mathrm{Ci})$ dengan $E R B$, apabila nilai $E R B$ lebih tinggi dibandingkan nilai $C i$ maka saham tersebut dapat dimasukkan ke dalam kombinasi saham untuk dapat membentuk portofolio optimal dan begitu pula sebaliknya.

Penelitian sebelumnya oleh Setyoningsih et al. (2015) yang meneliti pembentukan portofolio optimal berdasarkan Model Indeks Tunggal, dalam penelitiannya menunjukkan dari saham perusahaan yang tercatat dalam Indeks Kompas 100 yang digunakan, terdapat 12 saham saja yang dapat membentuk sebuah portofolio optimal. Darmawan \& Purnawati (2015) dalam penelitianya menunjukan hasil bahwa portofolio optimal hanya dapat dibentuk oleh tiga 
perusahaan dari 22 perusahaan yang dianalisis. Hasil yang berbeda diperoleh Harun et al. (2015) yang menunjukan dari saham Indeks Kompas 100 selama periode pengamatan dari 2013 sampai 2014 di Bursa Efek Indonesia, terdapat Sembilan saham perusahaan saja yang dapat membentuk portofolio optimal.

Temuan lainnya diungkapkan oleh Utamayasa \& Wiagustini (2016) dalam penelitiannya, yaitu terdapat dua saham perbankan yang bisa membentuk portofolio optimal dari 28 saham perbankan yang diteliti. Giri \& Parhi (2017) dalam penelitiannya menganalisis 50 sekuritas dan menghasilkan lima saham yang dapat membentuk portofolio optimal dengan menggunakan Model Indeks Tunggal. Penelitian terbaru mengenai pembentukan portofolio optimal juga dilakukan oleh Widyasari (2017) yang menghasilkan pembentukan protofolio optimal dengan komposisi saham untuk indeks Kompas 100 sebanyak 13 saham.

Penelitian yang dilakukan oleh Arisandy et al. (2017) tentang analisis investasi portofolio saham pasar modal dengan Model Indeks Tunggal studi kasus di Indeks Kompas 100 periode 2013-2015 memperoleh perhitungan Model Indeks Tunggal dari 30 saham yag dianalisis, diperoleh 20 saham yang dapat membentuk portofolio optimal. Rahmadin et al. (2014) dalam penelitiannya yang berjudul Pembentukan Portofolio Optimal Saham Berdasarkan Model Indeks Tunggal (Studi Pada Saham Indeks LQ 45 Di BEI Tahun 2011-2013) terdapat enam saham yang dapat membentuk sebuah portofolio optimal. Penelitian selanjutnya oleh Tana (2016) menyatakan bahwa dari 28 saham anggota di Jakarta Islamic Index (JII) yang digunakan untuk pembentukan portofolio optimal, terdapat 11 saham yang dapat membentuk portofolio optimal.

Hamdani \& Muhardi (2015) dalam penelitiannya pembentukan portofolio optimal pada Indeks Kompas 100 Periode 2013-2014 dari 100 sampel saham perusahaan terpilih terdapat 19 saham perusahaan yang membentuk komposisi portofolio optimal. Chintan (2015) meneliti tentang membentuk portofolio optimal di 15 saham BSE menggunakan Model Indeks Tunggal serta CAPM memperoleh hasil bahwa dari 15 saham yang digunakan, terdapat lima saham yang dapat membentuk sebuah portofolio optimal. Penelitian yang dilakukan oleh Lestari \& Candraningrat (2014) menghasilkan lima saham anggota Indeks LQ 45 yang terpilih untuk membentuk portofolio optimal dengan pendekatan Model Indeks Tunggal.

Indeks Kompas 100 selain memiliki likuiditas yang tinggi, serta nilai kapitalisasi pasar yang besar, juga merupakan saham-saham yang memiliki fundamental dan kinerja yang baik. Hal ini tercermin dari kriteria-kriteria pemilihan saham Indeks Kompas 100 berdasarkan pengumuman Jakarta Stock Exchange, sekarang bernama Bursa Efek Indonesia (BEI), pada 10 Agustus 2007 sebagai berikut (Jakarta Stock Exchange, 2007) : 1) Saham yang masuk dalam perhitungan indeks akan dievaluasi setiap enam bulan sekali, yaitu setiap akhir Januari dan akhir Juli. 2) Telah tercatat di BEI minimal 3 bulan dan masuk dalam perhitungan IHSG. 3) Seleksi saham dimulai dengan seleksi likuiditas, dengan menggunakan data transaksi di Pasar Reguler selama 12 bulan terakhir. 4) Sebagai saringan akhir, BEJ mengevaluasi dan mempertimbangkan faktor-faktor fundamental dan pola perdagangan saham yang telah melewati saringan likuiditas. nilai transaksi, jumlah hari transaksi, banyaknya transaksi dan kapitalisasi pasar. 
Saham-saham yang termasuk dalam Indeks Kompas 100 diperkirakan mewakili sekitar 70-80 persen dari total nilai kapitalisasi pasar seluruh saham yang tercatat di BEI, maka dengan demikian investor bisa melihat kecenderungan arah pergerakan indeks dengan mengamati pergerakan Indeks Kompas 100. Pergerakan indeks saham menunjukan dari harga saham-saham yang masuk kedalam kelompok Kompas 100. Semakin tinggi variasi pergerakan dari harga saham Kompas 100 semakin besar risiko yang ditanggung oleh investor.

Model Indeks Tunggal dikembangkan oleh William Sharpe. Model ini mengaitkan perhitungan return setiap aset pada return indeks pasar. Konsep Model Indeks Tunggal diciptakan oleh Sharpe yang berkeinginan untuk menyederhanakan perhitungan yang ada dalam Model Markowitz dengan menggunakan parameter input yang dibutuhkan dalam perhitungan Model Indeks Tunggal . Perhitungan return sekuritas dalam Model Indeks Tunggal melibatkan dua komponen utama yaitu Komponen return dengan keunikan perusahaan yang dilambangkan dengan alpha $(\alpha)$ dan Komponen return yang terkait dengan pasar dapat dilambangkan dengan simbol beta $(\beta)$ Salah satu konsep penting dalam Model Indeks Tunggal adalah terminology beta $(\beta)$. Nilai beta $(\beta)$ merupakan ukuran kepekaan return sekuritas terhadap return pasar. Semakin besar $\beta$ (beta) suatu sekuritas, semakin besar kepekaan return sekuritas tersebut terhadap perubahan return pasar. Teknik analisis portofolio optimal dengan Model Indeks Tunggal menyatakan bahwa return saham berfluktuasi searah dengan indeks harga pasar (Agmiviolya et al., 2014). Hal ini dapat dilihat bahwa kebanyakan saham cenderung mengalami kenaikan harga jika indeks harga naik dan sebaliknya, jika indeks harga turun maka saham akan mengalami penurunan harga (Qur'anitasari \& Sulasmiyati, 2016)

Return-return dari sekuritas ini kemungkinan berkolerasi karena adanya gerakan umum di pasar saham terhadap perubahan - perubahan nilai pasar (Gopalakrishnan, 2014). Teknik awal dalam portofolio optimal Model Indeks Tunggal dilakukan dengan cara menghitung return-return saham individual, dilanjutkan dengan menghitung varian saham dan pasar. Langkah selanjutnya mencari nilai Excess Return to Beta (ERB) masing-masing saham dan menyusun peringkat ERB dari yang terbesar hingga ke yang terendah. Setelah itu dilanjutkan dengan menghitung nilai cut-off rate (Ci) dan membandingkan dengan nilai ERB. Apabila hasil perhitungan ERB $\geq \mathrm{Ci}$, maka saham tersebut dapat dimasukkan kedalam portofolio optimal. Sedangkan apabila ERB < Ci maka saham tersebut belum tergolong saham yang dapat dibentuk portofolio optimal.

\section{METODE PENELITIAN}

Penelitian ini merupakan penelitian dengan menggunakan pendekatan kuantitatif yang berbentuk deskriptif. Bertujuan untuk mengetahui sahamsaham yang layak untuk dimasukan ke dalam penentuan portofolio optimal dengan menggunakan model Model Indeks Tunggal periode Agustus 2016 Januari 2019 yang terdaftar dalam Indeks Kompas 100 di Bursa Efek Indonesia. Penelitian ini dilakukan pada perusahaan-perusahaan yang sahamnya tercatat dalam Bursa Efek Indonesia (BEI) dan masuk ke dalam Indeks Kompas 100 serta aktif diperdagangkan selama periode Agustus 2016 
- Januari 2019. Obyek pada penelitian ini adalah saham Indeks Kompas 100 periode Agustus 2016 - Januari 2019. Variabel yang akan digunakan dalam judul penelitian ini meliputi expected return portofolio dan risiko portofolio. Expected return portofolio merupakan rata-rata tertimbang dari returnreturn ekspektasi masing-masing saham di dalam portofolio. Dihitung dengan mengalikan expected return masing-masing saham dengan bobot atau proporsi saham dalam portofolio. Expected return dapat dihitung dengan persamaan berikut.

$E\left(K_{p}\right)=\sum_{i=1}^{n} w_{l} \cdot E\left(K_{l}\right)$

Keterangan:

$E\left(K_{p}\right)=$ Expected return dari portofolio

$w_{l} \quad=$ Porsi dari saham i terhadap seluruh saham di portofolio

$E\left(K_{l}\right)=$ Expected return dari saham ke-i

$n \quad=$ Jumlah saham yang ada dalam portofolio

Risiko portofolio adalah penjumlahan dari standar deviasi dan kovarian sesuai dengan proporsi masing-masing saham di dalamnya. Maka risiko ini dapat dituliskan dalam bentuk perkalian matrik antar matrik kovarian dengan matrik proporsi masing-masing saham indeks kompas 100 periode Agustus 2016 - Januari 2019. Risiko portofolio dapat dihitung sebagai berikut.

$\sigma_{p}=\beta_{\mu^{2}} \cdot \sigma_{M^{2}}+\left(\sum_{i=1}^{n} w_{l} \cdot \sigma_{e}\right)^{2}$.

Keterangan:

$$
\begin{array}{ll}
\sigma_{p} & =\text { Risiko sekuritas } \\
\beta_{p} & =\text { beta sekuritas } \\
\sigma_{M^{2}} & =\text { kuadrat Varians return pasar } \\
W_{l} & =\text { Bobot atau proporsi sekuritas ke-i } \\
\sigma_{e} & =\text { varian dari kesalahan residu sekuritas ke-i }
\end{array}
$$

Jenis data yang digunakan dalam penelitian ini merupakan data kuantitatif dan data kualitatif. Data kuantitatif untuk penelitian ini terdiri atas: data closing price saham (harga saham penutupan), data Indeks Kompas 100, data tingkat suku bunga SBI. Data kualitatif yang digunakan dalam penelitian ini berupa data nama perusahaan yang terdapat di Indeks Kompas 100 Sumber data yang digunakan dalam penelitian ini adalah sumber data sekunder. Penelitian ini tidak secara langsung mengambil data sendiri tetapi meneliti dan memanfaatkan data dokumen yang dihasilkan oleh pihak-pihak lain. Sumber data dalam penelitian ini adalah Data harga saham penutupan bulanan dalam Indeks Kompas 100 periode Agustus 2016 - Januari 2019, data Indeks Kompas 100 di Bursa Efek Indonesia yang dapat diakses pada situs www.idx.co.id dan pada yahoo finance di situs finance.yahoo.com. dan Data suku bunga SBI yang dapat diakses melalui situs www.bi.go.id

Populasi penelitian ini adalah semua saham perusahaan yang tercatat di Bursa Efek Indonesia dan konsisten terdaftar ke dalam Indeks Kompas 100 selama periode Agustus 2016 - Januari 2019 yang berjumlah 77 saham. Sampel yang digunakan dalam penelitian ini diambil dengan metode slovin sehingga jumlah sampel yang didapat adalah 65 saham. Metode pengumpulan data menggunakan metode observasi nonpartisipan. Data saham yang merupakan anggota dari Indeks 
Kompas 100 periode Agustus 2016 - Januari 2019 didapat melalui www. idx.co.id. Harga penutupan saham perusahaan setiap bulan didapat melalui www.finance.yahoo.com. Data suku bunga SBI yang dapat diakses melalui situs www.bi.go.id

\section{HASIL DAN PEMBAHASAN}

Tahap pertama adalah menghitung masing-masing return saham (realisasi maupun ekspetasi) yang tergabung dalam indeks Kompas 100 periode Agustus 2016-Januari 2019 dan juga digunakan sebagai sampel penelitian. Berdasarkan Tabel 1, dapat dilihat bahwa return ekspetasi tertinggi diraih oleh saham Bumi Resources Tbk. (BUMI), sedangkan nilai return terkecil diperoleh oleh saham Lippo Karawaci Tbk. (LPKR).

\section{Tabel 1.}

Return Realisasi dan Return Ekspetasi Saham Indeks Kompas 100 Periode Agustus 2016-Januari 2019

\begin{tabular}{|c|c|c|c|}
\hline No & Kode Saham & $\underset{(\%)}{\sum \text { Rit }}$ & $\begin{array}{c}\mathbf{E}(\mathbf{R i}) \\
(\%)\end{array}$ \\
\hline 1 & AALI & -0.0751 & -0.0026 \\
\hline 2 & ACES & 0.62052 & 0.0214 \\
\hline 3 & ADHI & -0.3021 & -0.0104 \\
\hline 4 & ADRO & 0.34544 & 0.01191 \\
\hline 5 & AKRA & -0.1312 & -0.0045 \\
\hline 6 & ANTM & 0.54133 & 0.01867 \\
\hline 7 & ASII & 0.0737 & 0.0025 \\
\hline 8 & ASRI & -0.22252 & -0.00767 \\
\hline 9 & BBCA & 0.6667 & 0.023 \\
\hline 10 & BBNI & 0.52403 & 0.01807 \\
\hline 11 & BBRI & 0.56047 & 0.01933 \\
\hline 12 & BBTN & 0.48895 & 0.01686 \\
\hline 13 & BDMN & 0.9593 & 0.0331 \\
\hline 14 & BEST & 0.0038 & 0.00013 \\
\hline 15 & BHIT & -0.4587 & -0.0158 \\
\hline 16 & BJBR & 0.9623 & 0.03318 \\
\hline 17 & BJTM & 0.31383 & 0.01082 \\
\hline 18 & BKSL & 0.638 & 0.022 \\
\hline 20 & BMTR & -0.51531 & -0.01777 \\
\hline 21 & BSDE & -0.3879 & -0.0134 \\
\hline 22 & BUMI & 2.75658 & 0.09505 \\
\hline 23 & CPIN & 0.80976 & 0.02792 \\
\hline 24 & CTRA & -0.3424 & -0.0118 \\
\hline 25 & DOID & 1.7645 & 0.06084 \\
\hline 26 & ELSA & -0.1535 & -0.0053 \\
\hline 27 & GGRM & 0.31637 & 0.01091 \\
\hline 28 & GJTL & -0.4559 & -0.0157 \\
\hline 29 & HMSP & 0.0123 & 0.0004 \\
\hline 30 & ICBP & 0.10251 & 0.00353 \\
\hline 31 & INCO & 0.6911 & 0.0238 \\
\hline 32 & INDF & 0.0219 & 0.00076 \\
\hline 33 & INDY & 1.69561 & 0.05847 \\
\hline 34 & INTP & 0.27381 & 0.00944 \\
\hline
\end{tabular}

bersambung... 
Lanjutan Tabel 1.

\begin{tabular}{lccc}
\hline No & Kode Saham & $\begin{array}{c}\boldsymbol{\Sigma} \mathbf{R i t} \\
(\boldsymbol{\%})\end{array}$ & $\begin{array}{c}\mathbf{E}(\mathbf{R i}) \\
(\boldsymbol{\%})\end{array}$ \\
\hline 35 & ISAT & -0.5275 & -0.0182 \\
36 & ITMG & 1.00487 & 0.03465 \\
37 & JPFA & 0.7452 & 0.0257 \\
38 & JSMR & 0.09857 & 0.0034 \\
39 & KAEF & 0.2511 & 0.00866 \\
40 & KLBF & -0.0698 & -0.0024 \\
41 & LINK & 0.056 & 0.0019 \\
42 & LPKR & -1.22581 & -0.04227 \\
44 & MAPI & 0.8851 & 0.0305 \\
45 & MEDC & 1.75478 & 0.06051 \\
46 & MIKA & -0.5213 & -0.018 \\
47 & MNCN & -0.63678 & -0.02196 \\
48 & PBRX & 0.39609 & 0.01366 \\
49 & PGAS & 0.104 & 0.0036 \\
50 & PNBN & 0.63553 & 0.02191 \\
51 & PPRO & 0.1395 & 0.0048 \\
52 & PTPP & -0.3116 & -0.0107 \\
53 & PWON & 0.18123 & 0.00625 \\
54 & SCMA & -0.35976 & -0.01241 \\
55 & SMBR & 0.5179 & 0.0179 \\
56 & SMGR & 0.3987 & 0.01375 \\
57 & SMRA & -0.2915 & -0.0101 \\
58 & TARA & 0.3108 & 0.0107 \\
59 & TBIG & 0.03163 & 0.00109 \\
60 & TINS & 0.88449 & 0.0305 \\
61 & UNTR & 0.4117 & 0.0142 \\
62 & UNVR & 0.13288 & 0.00458 \\
63 & WIKA & -0.2127 & -0.0073 \\
64 & WSKT & -0.17762 & -0.0246 \\
65 & WTON & -0.7146 & \\
\hline
\end{tabular}

Sumber : Data Diolah, 2019

Tahap kedua yaitu menghitung nilai return realisasi pasar dan return ekspetasi pasar. Hasil perhitungan return realisasi dan ekspetasi pasar dapat dilihat pada Tabel 2. Berdasarkan hasil perhitungan, return ekspetasi dan risiko pasar indeks Kompas 100, dapat dilihat return realisasi pasar yang diperoleh pada periode Agustus 2016-Januari 2019 sebesar 0.1673 persen, return realisasi pasar sebesar 0.0058 persen dan risiko pasar 0.00121 persen

Tabel 2.

Return Realisasi, Return Ekspetasi dan Risiko Pasar Indeks Kompas 100 Periode Agustus 2016-Januari 2019

\begin{tabular}{|c|c|c|c|c|c|c|}
\hline \multirow{2}{*}{ NO } & \multirow{2}{*}{ BULAN } & \multirow{2}{*}{ TAHUN } & \multicolumn{4}{|c|}{ Indeks Kompas 100} \\
\hline & & & Indeks Saham & $\mathbf{R m}$ & $(\mathbf{R m}-\mathbf{E}(\mathbf{R m}))$ & $(\mathbf{R m}-\mathbf{E}(\mathbf{R m}))^{2}$ \\
\hline 1 & Agustus & 2016 & 1158.600 & & & \\
\hline 2 & September & 2016 & 1152.620 & -0.0052 & -0.0109 & 0.00012 \\
\hline
\end{tabular}


Lanjutan Tabel 2

\begin{tabular}{|c|c|c|c|c|c|c|}
\hline \multirow[b]{2}{*}{ NO } & \multirow[b]{2}{*}{ BULAN } & \multirow[b]{2}{*}{ TAHUN } & \multicolumn{4}{|c|}{ Indekes Kompas 100} \\
\hline & & & $\begin{array}{l}\text { Indeks } \\
\text { Saham }\end{array}$ & $\mathbf{R m}$ & $\begin{array}{c}(\mathbf{R m}- \\
\mathbf{E}(\mathbf{R m}))\end{array}$ & $\begin{array}{c}(\mathbf{R m}- \\
\mathbf{E}(\mathbf{R m}))^{2}\end{array}$ \\
\hline 3 & Oktober & 2016 & 1160.470 & 0.0068 & 0.0010 & 0.00000 \\
\hline 4 & November & 2016 & 1082.210 & -0.0674 & -0.0732 & 0.00536 \\
\hline 5 & Desember & 2016 & 1116.640 & 0.0318 & 0.0260 & 0.00068 \\
\hline 6 & Januari & 2017 & 1109.500 & -0.0064 & -0.0122 & 0.00015 \\
\hline 7 & Februari & 2017 & 1133.380 & 0.0215 & 0.0158 & 0.00025 \\
\hline 8 & Maret & 2017 & 1169.940 & 0.0323 & 0.0265 & 0.00070 \\
\hline 9 & April & 2017 & 1194.320 & 0.0208 & 0.0151 & 0.00023 \\
\hline 10 & Mei & 2017 & 1208.180 & 0.0116 & 0.0058 & 0.00003 \\
\hline 11 & Juni & 2017 & 1226.470 & 0.0151 & 0.0094 & 0.00009 \\
\hline 12 & Juli & 2017 & 1223.510 & -0.0024 & -0.0082 & 0.00007 \\
\hline 13 & Agustus & 2017 & 1224.960 & 0.0012 & -0.0046 & 0.00002 \\
\hline 14 & September & 2017 & 1228.410 & 0.0028 & -0.0030 & 0.00001 \\
\hline 15 & Oktober & 2017 & 1247.180 & 0.0153 & 0.0095 & 0.00009 \\
\hline 16 & November & 2017 & 1240.200 & -0.0056 & -0.0114 & 0.00013 \\
\hline 17 & Desember & 2017 & 1343.420 & 0.0832 & 0.0775 & 0.00600 \\
\hline 18 & Januari & 2018 & 1396.850 & 0.0398 & 0.0340 & 0.00116 \\
\hline 19 & Februari & 2018 & 1394.610 & -0.0016 & -0.0074 & 0.00005 \\
\hline 20 & Maret & 2018 & 1286.660 & -0.0774 & -0.0832 & 0.00692 \\
\hline 21 & April & 2018 & 1233.180 & -0.0416 & -0.0473 & 0.00224 \\
\hline 22 & Mei & 2018 & 1228.090 & -0.0041 & -0.0099 & 0.00010 \\
\hline 23 & Juni & 2018 & 1174.430 & -0.0437 & -0.0495 & 0.00245 \\
\hline 24 & Juli & 2018 & 1208.610 & 0.0291 & 0.0233 & 0.00054 \\
\hline 25 & Agustus & 2018 & 1226.640 & 0.0149 & 0.0091 & 0.00008 \\
\hline 26 & September & 2018 & 1216.390 & -0.0084 & -0.0141 & 0.00020 \\
\hline 27 & Oktober & 2018 & 1178.040 & -0.0315 & -0.0373 & 0.00139 \\
\hline 29 & Desember & 2018 & 1258.170 & 0.0200 & 0.0142 & 0.00020 \\
\hline 30 & Januari & 2019 & 1345.290 & 0.0692 & 0.0635 & 0.00403 \\
\hline \multicolumn{4}{|c|}{ Total } & 0.1673 & $\begin{array}{c}\text { Total } \\
\text { Variance }\end{array}$ & 0.03499 \\
\hline \multicolumn{4}{|c|}{$\mathbf{E}(\mathbf{R m})$} & 0.0058 & $\begin{array}{l}\text { Pasar } \\
\text { (OM²) }\end{array}$ & 0.00121 \\
\hline
\end{tabular}

Sumber : Data Diolah, 2019

Tahap Keempat dilakukan dengan cara menetukan peringkat saham berdasarkan nilai Excess Return to Beta (ERB). Menghitung ERB dapat dilakukan dengan mengurangi expected return masing-masing saham dengan tingkat bunga bebas risiko, yang nantinya mendapatkan hasil yang dibagi dengan beta saham yang dihitung. 
Tabel 3.

Expected Return dan Excess Return to Beta Masing-Masing SahamIndeks Kompas 100 Periode Agustus 2016 - Januari 2019

\begin{tabular}{|c|c|c|c|c|}
\hline NO & $\begin{array}{c}\text { KODE } \\
\text { SAHAM }\end{array}$ & NAMA SAHAM & $\mathbf{E}(\mathbf{R i})$ & $E R \beta(i)$ \\
\hline 1 & AALI & Astra Agro Lestari Tbk. & -0.0751 & -1.0202 \\
\hline 2 & ACES & Ace Hardware Indonesia Tbk. & 0.6205 & 0.3107 \\
\hline 3 & ADHI & Adhi Karya (Persero) Tbk. & -0.3021 & -0.3713 \\
\hline 4 & ADRO & Adaro Energy Tbk. & 0.3454 & -0.0648 \\
\hline 5 & AKRA & Akr Korporindo Tbk. & -0.1312 & -0.4564 \\
\hline 6 & ANTM & Aneka Tambang (Persero) Tbk. & 0.5413 & 0.1409 \\
\hline 7 & ASII & Astra International Tbk. & 0.0737 & -0.3648 \\
\hline 8 & ASRI & Alam Sutera Realty Tbk. & -0.2225 & -0.5950 \\
\hline 9 & BBCA & Bank Central Asia Tbk. & 0.6667 & 0.2544 \\
\hline 10 & BBNI & Bank Negara Indonesia (Persero) Tbk. & 0.5240 & 0.0741 \\
\hline 11 & BBRI & Bank Rakyat Indonesia (Persero) Tbk. & 0.5605 & 0.1105 \\
\hline 12 & BBTN & Bank Tabungan Negara Persero Tbk. & 0.4890 & 0.0467 \\
\hline 13 & BDMN & Bank Danamon Indonesia Tbk. & 0.9593 & 0.3623 \\
\hline 14 & BEST & Bekasi Fajar Industrial Estate Tbk. & 0.0038 & -0.2436 \\
\hline 15 & BHIT & Mnc Investama Tbk. & -0.4587 & -0.7901 \\
\hline 16 & BJBR & $\begin{array}{l}\text { Bank Pembangunan Jawa Barat Dan Banten } \\
\text { Tbk. }\end{array}$ & 0.9623 & 0.3483 \\
\hline 17 & BJTM & Bank Pembangunan Jawa Timur Tbk & 0.3138 & -0.1009 \\
\hline 18 & BKSL & Sentul City Tbk. & 0.6380 & 0.3385 \\
\hline 19 & BMRI & Bank Mandiri (Persero) Tbk. & 0.3184 & -0.0953 \\
\hline 20 & BMTR & Global Mediacom Tbk. & -0.5153 & -0.4672 \\
\hline 21 & BSDE & Bumi Serpong Damai Tbk. & -0.3879 & -0.6309 \\
\hline 22 & BUMI & Bumi Resources Tbk. & 2.7566 & 2.9194 \\
\hline 23 & CPIN & Charoen Pokphand Indonesia Tbk. & 0.8098 & 0.4552 \\
\hline 24 & CTRA & Ciputra Development Tbk. & -0.3424 & -0.8405 \\
\hline 25 & DOID & Delta Dunia Makmur Tbk. & 1.7645 & 0.9884 \\
\hline 26 & ELSA & Elnusa Tbk. & -0.1535 & -0.8682 \\
\hline 27 & GGRM & Gudang Garam Tbk. & 0.3164 & -0.0976 \\
\hline 28 & GJTL & Gajah Tunggal Tbk. & -0.4559 & -0.6186 \\
\hline 29 & HMSP & H. M. Sampoerna Tbk. & 0.0123 & -0.3236 \\
\hline 30 & ICBP & Indofood Cbp Sukses Makmur Tbk. & 0.1025 & -0.5240 \\
\hline 31 & INCO & Vale Indonesia Tbk. & 0.6911 & 0.6149 \\
\hline 32 & INDF & Indofood Sukses Makmur Indonesia & 0.0219 & -0.4395 \\
\hline 33 & INDY & Indika Energy Tbk. & 1.6956 & 0.9169 \\
\hline 34 & INTP & Indocement Tunggal Perkasa Tbk. & 0.2738 & -0.0730 \\
\hline
\end{tabular}

Bersambung... 


\begin{tabular}{|c|c|c|c|c|}
\hline NO & $\begin{array}{c}\text { KODE } \\
\text { SAHAM } \\
\end{array}$ & NAMA SAHAM & $\mathbf{E}(\mathbf{R i})$ & $E R \boldsymbol{\beta}(\mathbf{i})$ \\
\hline 35 & ISAT & Indosat Tbk. & -0.5275 & -0.4822 \\
\hline 36 & ITMG & Indo Tambangraya Megah Tbk. & 1.0049 & 0.4167 \\
\hline 37 & JPFA & Japfa Comfeed Indonesia Tbk. & 0.7452 & 0.2972 \\
\hline 38 & JSMR & Jasa Marga (Persero) Tbk. & 0.0986 & -0.2663 \\
\hline 39 & KAEF & Kimia Farma (Persero) Tbk & 0.2511 & -0.2222 \\
\hline 40 & KLBF & Kalbe Farma Tbk. & -0.0698 & -0.4434 \\
\hline 41 & LINK & Link Net Tbk. & 0.0560 & -0.7079 \\
\hline 42 & LPKR & Lippo Karawaci Tbk. & -1.2258 & -1.6880 \\
\hline 43 & LPPF & Matahari Department Store Tbk. & -0.8230 & -0.9523 \\
\hline 44 & MAPI & Mitra Adiperkasa Tbk. & 0.8851 & 1.1451 \\
\hline 45 & MEDC & Medco Energi Internasional Tbk. & 1.7548 & 0.5602 \\
\hline 46 & MIKA & Mitra Keluarga Karyasehat Tbk. & -0.5213 & -1.5567 \\
\hline 47 & $\mathrm{MNCN}$ & Media Nusantara Citra Tbk. & -0.6368 & -0.5676 \\
\hline 48 & PBRX & Pan Brothers Tbk. & 0.3961 & -0.0166 \\
\hline 49 & PGAS & Perusahaan Gas Negara (Persero) Tbk. & 0.1040 & -0.2333 \\
\hline 50 & PNBN & Bank Pan Indonesia Tbk. & 0.6355 & 0.2129 \\
\hline 51 & PPRO & Pp Property Tbk. & 0.1395 & -0.2873 \\
\hline 52 & РТРP & Pp (Persero) Tbk. & -0.3116 & -0.3246 \\
\hline 53 & PWON & Pakuwon Jati Tbk. & 0.1812 & -0.2157 \\
\hline 54 & SCMA & Surya Citra Media Tbk. & -0.3598 & -0.5262 \\
\hline 55 & SMBR & Semen Baturaja (Persero) Tbk. & 0.5179 & 0.1043 \\
\hline 56 & SMGR & Semen Indonesia (Persero) Tbk. & 0.3987 & -0.0043 \\
\hline 57 & SMRA & Summarecon Agung Tbk. & -0.2915 & -0.3214 \\
\hline 58 & TARA & Sitara Propertindo Tbk. & 0.3108 & -0.2246 \\
\hline 59 & TBIG & Tower Bersama Infrastructure Tbk. & 0.0316 & -0.2947 \\
\hline 60 & TINS & Timah (Persero) Tbk. & 0.8845 & 0.3469 \\
\hline 61 & UNTR & United Tractors Tbk. & 0.4117 & 0.0108 \\
\hline 62 & UNVR & Unilever Indonesia Tbk. & 0.1329 & -0.2865 \\
\hline 63 & WIKA & Wijaya Karya (Persero) Tbk. & -0.2127 & -0.3510 \\
\hline 64 & WSKT & Waskita Karya (Persero) Tbk. & -0.1776 & -0.3092 \\
\hline 65 & WTON & Wijaya Karya Beton Tbk. & -0.7146 & -0.9549 \\
\hline
\end{tabular}

Sumber : Data Diolah, 2019

Saham yang memiliki nilai ERB yang paling tinggi adalah saham Bumi Resources Tbk. (BUMI) dengan nilai ERB sebesar 0.1130, sedangkan ERB dengan nilai yang terkecil sebesar -0.0479 yang diperoleh oleh saham Lippo Karawaci Tbk. (LPKR). Tahap kelima, dilakukan dengan cara mencari titik pembatas yang digunakan untuk menentukan saham mana saja yang dapat dipilih untuk memebentuk sebuah portofolio optimal atau tidak. Mencari titik 
pembatas dapat dilakukan dengan menghitung nilai $\mathrm{Ci}$. Nilai $\mathrm{Ci}$ yang diperoleh dapat ditentukan mana yang akan menjadi titik pembatas untuk menentukan nilai Cut OffPoint $\left(\mathrm{C}^{*}\right)$. nilai Cut OffPoint $\left(\mathrm{C}^{*}\right)$ ini dipilih melalui nilai $\mathrm{Ci}$ yang terbesar.. Nilai dari Cut-Off Rate yang terbesar akan menjadi pembatas saham mana saja yang membentuk dapat portofolio optimal (Cut-Off Point) adalah Saham Aneka Tambang (Persero) Tbk. (ANTM) dengan nilai sebesar 0.015237267 .

Tabel 4.

Cut-Off Rate dan Cut-Off Point Saham Indeks Kompas 100 Periode Agustus 2016-Januari 2019

\begin{tabular}{|c|c|c|c|c|c|c|c|}
\hline No & $\begin{array}{l}\text { Nama } \\
\text { Saham }\end{array}$ & $E R \boldsymbol{\beta}(\mathbf{i})$ & $\boldsymbol{c}^{2}$ & $\sum_{I=1}^{[} A_{I}$ & $\sum_{I=1}^{L} B_{I}$ & $\mathbf{C i}$ & $C^{*}$ \\
\hline 1 & BUMI & 0.1130 & 0.225328 & 0.3251 & 2.8759 & 0.000390894 & \\
\hline 2 & MAPI & 0.0633 & 0.006847 & 1.9402 & 28.3949 & 0.002263674 & \\
\hline 3 & INCO & 0.0427 & 0.022787 & 2.3419 & 37.8024 & 0.002702627 & \\
\hline 4 & DOID & 0.0413 & 0.075315 & 3.3778 & 62.8689 & 0.003788459 & \\
\hline 5 & INDY & 0.0387 & 0.040861 & 5.2498 & 111.2480 & 0.005585028 & \\
\hline 6 & CPIN & 0.0269 & 0.007628 & 8.0208 & 214.1524 & 0.007691022 & \\
\hline 7 & BKSL & 0.0262 & 0.032320 & 8.4004 & 228.6280 & 0.007944709 & \\
\hline 8 & ACES & 0.0252 & 0.005675 & 10.5049 & 312.2853 & 0.009206627 & \\
\hline 9 & MEDC & 0.0235 & 0.048635 & 13.2984 & 431.4094 & 0.010553131 & \\
\hline 10 & ITMG & 0.0213 & 0.020877 & 15.4022 & 530.1826 & 0.011334241 & \\
\hline 11 & UNTR & 0.0209 & 0.006457 & 16.1632 & 566.6145 & 0.01158369 & \\
\hline 12 & TINS & 0.0192 & 0.032581 & 17.2813 & 624.8973 & 0.011888414 & \\
\hline 13 & BDMN & 0.0190 & 0.008517 & 22.4798 & 898.2993 & 0.013016433 & \\
\hline 14 & JPFA & 0.0190 & 0.013477 & 24.3097 & 994.7334 & 0.013331589 & \\
\hline 15 & BBCA & 0.0185 & 0.001068 & 42.4369 & 1974.6456 & 0.015137804 & \\
\hline 16 & BJBR & 0.0182 & 0.061858 & 43.1882 & 2015.8242 & 0.015182777 & \\
\hline 17 & PNBN & 0.0166 & 0.012583 & 44.7146 & 2107.8341 & 0.015226857 & \\
\hline 18 & TARA & 0.0156 & 0.002881 & 45.6981 & 2170.8169 & 0.015235008 & \\
\hline 19 & PBRX & 0.0154 & 0.007715 & 46.4753 & 2221.4478 & 0.015236922 & \\
\hline 20 & ANTM & 0.0153 & 0.018241 & 47.2414 & 2271.6573 & 0.015237267 & $\mathrm{C}^{*}$ \\
\hline 21 & SMBR & 0.0129 & 0.036744 & 47.6423 & 2302.7001 & 0.015214243 & \\
\hline 22 & BBRI & 0.0109 & 0.001478 & 62.0405 & 3617.7864 & 0.013952619 & \\
\hline 23 & BBNI & 0.0088 & 0.003104 & 69.2012 & 4429.1885 & 0.013161336 & \\
\hline 24 & ADRO & 0.0083 & 0.010229 & 69.9239 & 4515.9376 & 0.013082927 & \\
\hline 25 & BMRI & 0.0075 & 0.001354 & 74.6434 & 5146.5316 & 0.012492075 & \\
\hline 26 & GGRM & 0.0074 & 0.002873 & 76.8426 & 5443.0862 & 0.012252057 & \\
\hline 27 & BJTM & 0.0074 & 0.006145 & 77.8522 & 5580.2296 & 0.012147395 & \\
\hline 28 & BBTN & 0.0072 & 0.008634 & 80.4724 & 5942.2594 & 0.011884876 & \\
\hline
\end{tabular}

bersambung... 
Lanjutan Tabel 4.

\begin{tabular}{|c|c|c|c|c|c|c|c|}
\hline No & $\begin{array}{c}\text { Kode } \\
\text { Saham }\end{array}$ & $E R \boldsymbol{\beta}(\mathbf{i})$ & $\omega^{2}$ & $\sum_{\Gamma=1}^{i} A_{I}$ & $\sum_{T=1}^{i} B_{T}$ & $\mathbf{C i}$ & $\mathrm{C}^{*}$ \\
\hline 29 & KAEF & 0.0066 & 0.018544 & 80.6455 & 5968.6070 & 0.011864284 & \\
\hline 30 & SMGR & 0.0054 & 0.007447 & 82.9783 & 6400.7658 & 0.011477741 & \\
\hline 31 & INTP & 0.0030 & 0.009083 & 84.0539 & 6764.2274 & 0.011069984 & \\
\hline 32 & PWON & 0.0021 & 0.005458 & 84.4719 & 6963.9316 & 0.010839925 & \\
\hline 33 & PPRO & 0.0008 & 0.029401 & 84.4954 & 6993.2853 & 0.010802261 & \\
\hline 34 & UNVR & 0.0005 & 0.001873 & 84.7593 & 7480.1836 & 0.010201014 & \\
\hline 35 & PGAS & -0.0004 & 0.018727 & 84.7263 & 7569.8750 & 0.010088142 & \\
\hline 36 & JSMR & -0.0006 & 0.004479 & 84.5545 & 7868.2106 & 0.009722332 & \\
\hline 37 & ICBP & -0.0009 & 0.001394 & 84.3342 & 8109.4803 & 0.009435248 & \\
\hline 38 & ASII & -0.0017 & 0.001623 & 83.4785 & 8621.9655 & 0.008833056 & \\
\hline 39 & TBIG & -0.0023 & 0.009878 & 83.0956 & 8785.7587 & 0.008642746 & \\
\hline 40 & BEST & -0.0024 & 0.013453 & 82.6123 & 8988.8605 & 0.008414722 & \\
\hline 41 & HMSP & -0.0030 & 0.001673 & 79.9606 & 9875.8100 & 0.007469786 & \\
\hline 42 & INDF & -0.0038 & 0.002216 & 78.6541 & 10221.2692 & 0.007118022 & \\
\hline 43 & LINK & -0.0043 & 0.005150 & 78.4492 & 10268.8483 & 0.007069036 & \\
\hline 44 & WSKT & -0.0054 & 0.007589 & 75.9129 & 10739.0563 & 0.00656244 & \\
\hline 45 & KLBF & -0.0060 & 0.001711 & 71.8508 & 11413.3834 & 0.005869152 & \\
\hline 46 & WIKA & -0.0065 & 0.014846 & 70.4965 & 11622.9832 & 0.00566159 & \\
\hline 47 & SMRA & -0.0065 & 0.011256 & 67.7724 & 12042.0855 & 0.005265585 & \\
\hline 48 & РTPP & -0.0067 & 0.013269 & 65.3035 & 12410.8396 & 0.004932446 & \\
\hline 49 & AKRA & -0.0073 & 0.006069 & 63.6368 & 12639.4755 & 0.004724966 & \\
\hline 50 & ADHI & -0.0076 & 0.009732 & 60.7979 & 13013.5432 & 0.004392187 & \\
\hline 51 & BMTR & -0.0111 & 0.022206 & 58.8579 & 13188.8458 & 0.004198864 & \\
\hline 52 & ASRI & -0.0111 & 0.005999 & 56.7897 & 13375.0947 & 0.003998197 & \\
\hline 53 & SCMA & -0.0113 & 0.005353 & 52.3103 & 13771.0909 & 0.00358294 & \\
\hline 54 & ISAT & -0.0115 & 0.018785 & 50.0156 & 13970.8219 & 0.003379536 & \\
\hline 55 & BSDE & -0.0139 & 0.004254 & 44.8544 & 14343.4348 & 0.002956362 & \\
\hline 56 & AALI & -0.0141 & 0.006009 & 44.3318 & 14380.5079 & 0.002914795 & \\
\hline 57 & MNCN & -0.0142 & 0.008000 & 38.3528 & 14802.8112 & 0.002453554 & \\
\hline 58 & GJTL & -0.0142 & 0.010055 & 35.6098 & 14996.0651 & 0.002250253 & \\
\hline 59 & ELSA & -0.0145 & 0.011172 & 35.0695 & 15033.3024 & 0.00221091 & \\
\hline 60 & CTRA & -0.0178 & 0.007527 & 33.1908 & 15138.7691 & 0.002078648 & \\
\hline 61 & BHIT & -0.0182 & 0.012799 & 31.4898 & 15232.4504 & 0.001960619 & \\
\hline 62 & WTON & -0.0245 & 0.007890 & 27.2186 & 15407.1308 & 0.001676448 & \\
\hline 63 & LPPF & -0.0251 & 0.012547 & 23.8804 & 15539.9689 & 0.001458904 & \\
\hline 64 & MIKA & -0.0370 & 0.005734 & 21.5893 & 15601.9193 & 0.001313967 & \\
\hline 65 & LPKR & -0.0479 & 0.006506 & 14.7030 & 15745.6399 & 0.000887091 & \\
\hline
\end{tabular}

Sumber : Data Diolah, 2019 
Tahap Keenam yaitu menentukan kandidat saham-saham yang menjadi sampel penelitian yang akan dijadikan portofolio optimal dengan membandingkan nilai ERB dengan nilai $\mathrm{C}^{*}$, yang dimana untuk menjadikan saham-saham pada sampel menjadi portofolio optimal ERB $\geq^{*}$.

Tabel 5.

Saham-Saham Indeks Kompas 100 yang Dapat Membentuk Portofolio Optimal Periode Agustus 2016-Januari 2019

\begin{tabular}{clccc}
\hline No & Kode Saham & ER $\boldsymbol{\beta}(\mathbf{i})$ & $\mathbf{C i}$ & Keterangan \\
\hline 1 & BUMI & 0.1130 & 0.000390894 & Kandidat \\
2 & MAPI & 0.0633 & 0.002263674 & Kandidat \\
3 & INCO & 0.0427 & 0.002702627 & Kandidat \\
4 & DOID & 0.0413 & 0.003788459 & Kandidat \\
5 & INDY & 0.0387 & 0.005585028 & Kandidat \\
6 & CPIN & 0.0269 & 0.007691022 & Kandidat \\
7 & BKSL & 0.0262 & 0.007944709 & Kandidat \\
8 & ACES & 0.0252 & 0.009206627 & Kandidat \\
9 & MEDC & 0.0235 & 0.010553131 & Kandidat \\
10 & ITMG & 0.0213 & 0.011334241 & Kandidat \\
11 & UNTR & 0.0209 & 0.01158369 & Kandidat \\
12 & TINS & 0.0192 & 0.011888414 & Kandidat \\
13 & BDMN & 0.0190 & 0.013016433 & Kandidat \\
14 & JPFA & 0.0190 & 0.013331589 & Kandidat \\
15 & BBCA & 0.0185 & 0.015137804 & Kandidat \\
16 & BJBR & 0.0182 & 0.015182777 & Kandidat \\
17 & PNBN & 0.0166 & 0.015226857 & Kandidat \\
18 & TARA & 0.0156 & 0.015235008 & Kandidat \\
19 & PBRX & 0.0154 & 0.015236922 & Kandidat \\
20 & ANTM & 0.0153 & 0.015237267 & Kandidat \\
\hline Sumber & Data Dion & & \\
\hline
\end{tabular}

Berdasarkan Tabel 5. dapat dilihat bahwa terdapat beberapa saham yang memiliki nilai ERB lebih besar dibandingkan nilai $\mathrm{C}^{*}$, saham-saham tersebut adalah Bumi Resources Tbk. (BUMI), Mitra Adiperkasa Tbk. (MAPI), Vale Indonesia Tbk. (INCO), Delta Dunia Makmur Tbk. (DOID), Indika Energy Tbk. (INDY), Charoen Pokphand Indonesia Tbk. (CPIN), Sentul City Tbk. (BKSL), Ace Hardware Indonesia Tbk. (ACES), Medco Energi Internasional Tbk. (MEDC), Indo Tambangraya Megah Tbk. (ITMG), United Tractors Tbk. (UNTR), Timah (Persero) Tbk. (TINS), Bank Danamon Indonesia Tbk. (BDMN), Japfa Comfeed Indonesia Tbk. (JPFA), Bank Central Asia Tbk. (BBCA), Bank Pembangunan Jawa Barat Dan Banten Tbk. (BJBR), Bank Pan Indonesia Tbk. (PNBN), Sitara Propertindo Tbk. (TARA), Pan Brothers Tbk. (PBRX), Aneka Tambang 
(Persero) Tbk. (ANTM). Saham-saham inilah yang bisa dimasukkan untuk dapat membentuk sebuah portofolio optimal.

Setelah mengetahui saham-saham apa saja yang dapat membentuk portofolio optimal, selanjutnya dilakukan perhitungan proporsi dana (Wi) dari saham-saham yang bisa membentuk portofolio optimal. Proporsi dana (Wi) dapat dihitung dengan cara membagi $\mathrm{Zi}$ dengan total $\mathrm{Zi}\left(\sum \mathrm{Zi}\right)$. $\mathrm{Zi}$ ini dapat diperoleh dengan membagi beta $(\beta)$ dengan varian residu $\left(\sigma^{2}\right.$ ei) kemudian dikalikan dengan selisih excess return to beta dengan cut-off point (Ci). Hasil perhitungan proporsi dana masing-masing saham adalah sebagai berikut.

Tabel 6.

Proporsi Dana Portofolio Optimal Saham Indeks Kompas 100 Periode Agustus 2016-Januari 2019

\begin{tabular}{clcc}
\hline NO & KODE SAHAM & $\mathbf{Z i}$ & $\mathbf{W i}$ \\
\hline 1 & BUMI & 0.3494 & $2.55 \%$ \\
2 & MAPI & 2.9338 & $21.40 \%$ \\
3 & INCO & 0.5579 & $4.07 \%$ \\
4 & DOID & 0.4759 & $3.47 \%$ \\
5 & INDY & 0.8071 & $5.89 \%$ \\
6 & CPIN & 1.3578 & $9.90 \%$ \\
7 & BKSL & 0.2325 & $1.70 \%$ \\
8 & ACES & 1.2043 & $8.78 \%$ \\
9 & MEDC & 0.4065 & $2.96 \%$ \\
10 & ITMG & 0.4170 & $3.04 \%$ \\
11 & UNTR & 0.4245 & $3.10 \%$ \\
12 & TINS & 0.1669 & $1.22 \%$ \\
13 & BDMN & 0.6766 & $4.94 \%$ \\
14 & JPFA & 0.3162 & $2.31 \%$ \\
15 & BBCA & 3.1242 & $22.79 \%$ \\
16 & BJBR & 0.0776 & $0.57 \%$ \\
17 & PNBN & 0.1156 & $0.84 \%$ \\
18 & TARA & 0.0559 & $0.41 \%$ \\
19 & PBRX & 0.0092 & $0.07 \%$ \\
20 & ANTM & 0.0011 & $0.01 \%$ \\
\hline
\end{tabular}

Sumber : Data Diolah, 2019

Berdasarkan Tabel 6. dapat dilihat bahwa proporsi dana yang disumbangkan masing-masing saham yang dapat membentuk portofolio optimal yaitu, BUMI sebesar 2.55 persen, MAPI sebesar 21.40 persen, INCO sebesar 4.07 persen, DOID sebesar 3.47 persen, INDY sebesar 5.89 persen, CPIN sebesar 9.90 persen, BKSL sebesar 1.70 persen, ACES sebesar 8.78 persen, MEDC sebesar 2.96 persen, ITMG sebesar 3.04 persen, UNTR sebesar 3.10 persen, TINS sebesar 1.22 persen, BDMN sebesar 4.94 persen, 
JPFA sebesar 2.31 persen, BBCA sebesar 22.79 persen, BJBR sebesar 0.57 persen, PNBN sebesar 0.84 persen, TARA sebesar 0.41 persen, PBRX sebesar 0.07 persen, dan ANTM sebesar 0.01 persen.

Tahap terakhir yaitu menghitung besarnya return ekspetasi portofolio dan risiko portofolio. Return ekspetasi portofolio dapat dihitung dengan cara menjumlahkan alpa dengan hasil kali dari beta dan return market (return pasar), sedangkan risiko portofolio dapat dihitung dengan cara menjumlahkan risiko sistematik portofolio dengan risiko unik portofolio. Berikut merupakan hasil perhitungan expected return portofolio dan risiko portofolio.

Tabel 7.

Expected Return Portofolio dan Risiko Portofolio Saham Indeks Kompas 100 Periode Agustus 2016-Januari 2019

\begin{tabular}{clcc}
\hline NO & Kode Saham & E(Rp) Ekspekted Return & $\boldsymbol{O p}^{2}$ (Risiko) \\
\hline 1 & BUMI & 0.002422 & 0.00014683 \\
2 & MAPI & 0.006531 & 0.00032318 \\
3 & INCO & 0.000970 & 0.00003816 \\
4 & DOID & 0.002112 & 0.00009350 \\
5 & INDY & 0.003442 & 0.00014989 \\
6 & CPIN & 0.002765 & 0.00008412 \\
7 & BKSL & 0.000373 & 0.00000945 \\
8 & ACES & 0.001880 & 0.00004821 \\
9 & MEDC & 0.001794 & 0.00004890 \\
10 & ITMG & 0.001054 & 0.00002161 \\
11 & UNTR & 0.000439 & 0.00000646 \\
12 & TINS & 0.000371 & 0.00000517 \\
13 & BDMN & 0.001633 & 0.00002759 \\
14 & JPFA & 0.000593 & 0.00000800 \\
15 & BBCA & 0.005239 & 0.00012103 \\
16 & BJBR & 0.000188 & 0.00000208 \\
17 & PNBN & 0.000185 & 0.00000099 \\
18 & TARA & 0.000044 & 0.00000005 \\
19 & PBRX & 0.000009 & 0.00000000 \\
20 & ANTM & 0.000001 & 0.00000000 \\
& Total & $\mathbf{0 . 0 3 2 0 4 5}$ & $\mathbf{0 . 0 0 1 1 3 5}$ \\
\hline
\end{tabular}

Sumber : Data Diolah, 2019

Dilihat dari Tabel 7. portofolio optimal yang dibentuk oleh beberapa saham Indeks Kompas 100 antara lain BUMI, MAPI, INCO, DOID, INDY, CPIN, BKSL, ACES, MEDC, ITMG, UNTR, TINS, BDMN, JPFA, BBCA, BJBR, PNBN, TARA, PBRX, dan ANTM memperoleh expected return portofolio sebesar 3.20 persen, sedangkan risiko portofolio yang kemungkinan akan diperoleh yaitu sebesar 0,11 persen. 
Berdasarkan hasil perhitungan portofolio optimal yang telah dilakukan menggunakan pendekatan model indeks tunggal sebelumnya didapatkan hasil bahwa dari 65 saham yang tergabung dan digunakan sebagai sampel penelitian dalam Indeks Kompas 100 periode Agustus 2016-Januari 2019 terdapat 20 saham yang dapat membentuk sebuah portofolio optimal, sahamsaham tersebut antara lain Bumi Resources Tbk. (BUMI), Mitra Adiperkasa Tbk. (MAPI), Vale Indonesia Tbk. (INCO), Delta Dunia Makmur Tbk. (DOID), Indika Energy Tbk. (INDY), Charoen Pokphand Indonesia Tbk. (CPIN), Sentul City Tbk. (BKSL), Ace Hardware Indonesia Tbk. (ACES), Medco Energi Internasional Tbk. (MEDC), Indo Tambangraya Megah Tbk. (ITMG), United Tractors Tbk. (UNTR), Timah (Persero) Tbk. (TINS), Bank Danamon Indonesia Tbk. (BDMN), Japfa Comfeed Indonesia Tbk. (JPFA), Bank Central Asia Tbk. (BBCA), Bank Pembangunan Jawa Barat Dan Banten Tbk. (BJBR), Bank Pan Indonesia Tbk. (PNBN), Sitara Propertindo Tbk. (TARA), Pan Brothers Tbk. (PBRX), Aneka Tambang (Persero) Tbk. (ANTM).

Proporsi dana saham yang dapat membentuk portofolio optimal dapat dilihat pada Gambar 1.

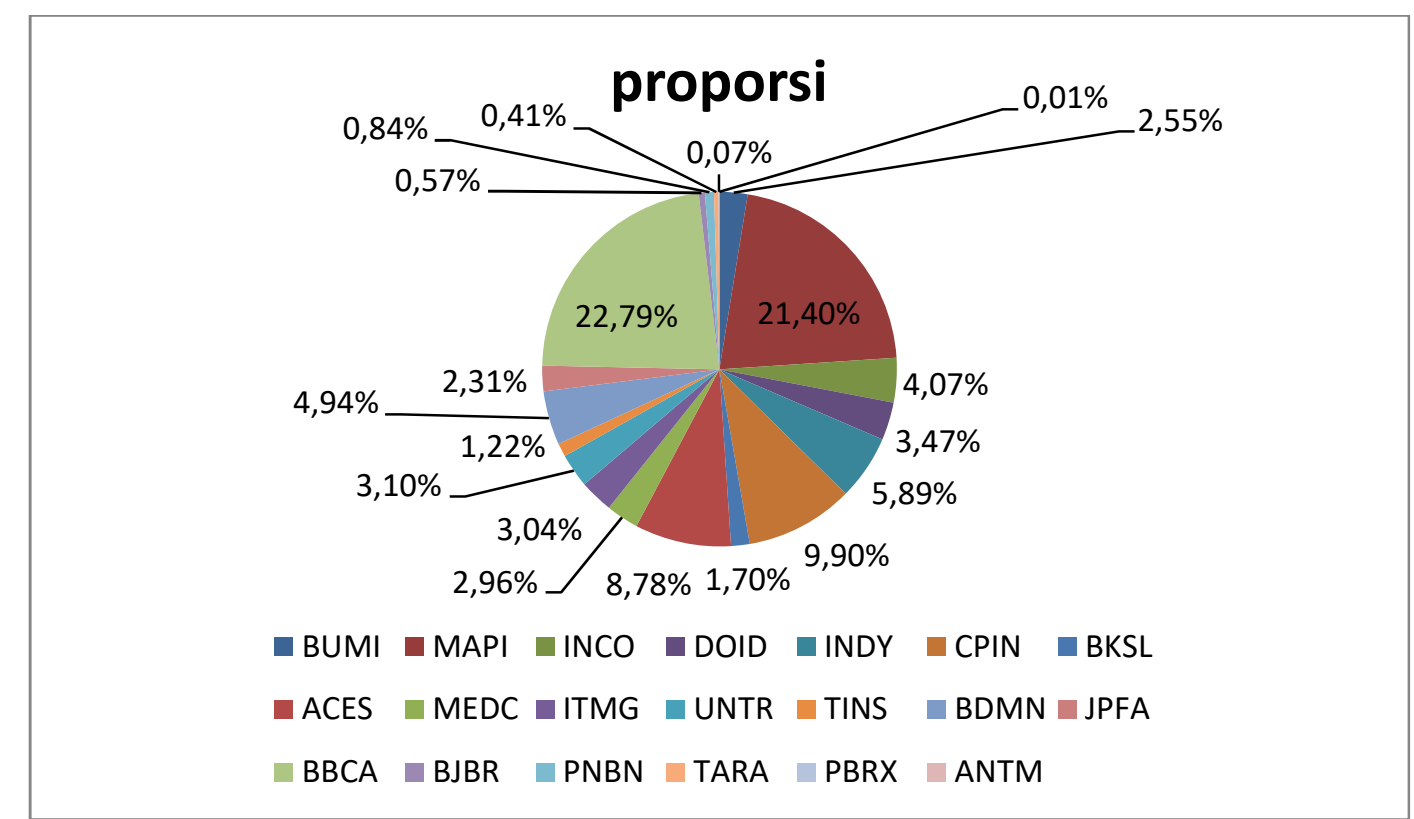

\section{Gambar 1. Proporsi Dana Masing-Masing Saham Pembentuk Portofolio Optimal}

Sumber : Data Diolah, 2019

Gambar 1. menunjukkan besarnya proporsi dana yang disumbangkan oleh masing-masing saham untuk dapat membentuk portofolio optimal, antara lain: BUMI sebesar 2.55 persen, MAPI sebesar 21.40 persen, INCO sebesar 4.07 persen, DOID sebesar 3.47 persen, INDY sebesar 5.89 persen, CPIN sebesar 9.90 persen, BKSL sebesar 1.70 persen, ACES sebesar 8.78 persen, MEDC sebesar 2.96 persen, ITMG sebesar 3.04 persen, UNTR sebesar 3.10 persen, TINS sebesar 1.22 persen, BDMN sebesar 4.94 persen, JPFA sebesar 
2.31 persen, BBCA sebesar 22.79 persen, BJBR sebesar 0.57 persen, PNBN sebesar 0.84 persen, TARA sebesar 0.41 persen, PBRX sebesar 0.07 persen, dan ANTM sebesar 0.01 persen. Portofolio merupakan gabungan dari beberapa sekuritas yang bertujuan untuk menghasilkan kombinasi efisen sehingga bisa memenuhi tujuan investor untuk memperoleh return yang tinggi dan memperkecil risiko yang akan diterima dikemudian hari. Tujuan utama dari pemilihan portofolio adalah mengelompokkan dan membentuk portofolio yang menghasilkan expected return yang maksimum dengan risiko yang seminimum mungkin.

Berdasarkan hasil penelitian yang telah dijabarkan sebelumnya, dapat diperoleh dua hasil implikasi penelitian, yaitu hasil penelitian ini memberikan implikasi teoretis yang menyatakan bahwa saham dalam Indeks Kompas 100 dapat digunakan untuk membentuk portofolio optimal dengan menggunakan Model Indeks Tunggal. Hasil penelitian tersebut diatas memberikan implikasi praktis untuk para investor yaitu investor yang ingin memilih saham-saham pada Indeks Kompas 100 dalam periode Agustus 2016-Januari 2019 untuk dijadikan portofolio optimal dengan menggunakan Model Indeks Tunggal dapat menggunakan saham Bumi Resources Tbk. (BUMI), Mitra Adiperkasa Tbk. (MAPI), Vale Indonesia Tbk. (INCO), Delta Dunia Makmur Tbk. (DOID), Indika Energy Tbk. (INDY), Charoen Pokphand Indonesia Tbk. (CPIN), Sentul City Tbk. (BKSL), Ace Hardware Indonesia Tbk. (ACES), Medco Energi Internasional Tbk. (MEDC), Indo Tambangraya Megah Tbk. (ITMG), United Tractors Tbk. (UNTR), Timah (Persero) Tbk. (TINS), Bank Danamon Indonesia Tbk. (BDMN), Japfa Comfeed Indonesia Tbk. (JPFA), Bank Central Asia Tbk. (BBCA), Bank Pembangunan Jawa Barat Dan Banten Tbk. (BJBR), Bank Pan Indonesia Tbk. (PNBN), Sitara Propertindo Tbk. (TARA), Pan Brothers Tbk. (PBRX), Aneka Tambang (Persero) Tbk. (ANTM). Saham-saham inilah yang dapat dipilih investor untuk investasi mendatang apabila investor ingin membentuk sebuah portofolio, dan juga melalui saham ini return yang bisa diperoleh investor dikemudian hari optimal dengan risiko yang minimum.

\section{SIMPULAN}

Berdasarkan hasil serta pembahasan, dapat ditarik kesimpulan yaitu Return Ekspetasi (Expected Return) portofolio yang diperoleh dari pembentukan portofolio optimal pada saham yang tergabung dalam Indeks Kompas 100 periode Agustus 2016-Januari 2019 yaitu sebesar 3.20 persen dengan risiko portofolio sebesar 0.11 persen. Proporsi yang dihasilkan dari pembentukan portofolio optimal pada saham Indeks Kompas 100, yaitu saham BUMI sebesar 2.55 persen, MAPI sebesar 21.40 persen, INCO sebesar 4.07 persen, DOID sebesar 3.47 persen, INDY sebesar 5.89 persen, CPIN sebesar 9.90 persen, BKSL sebesar 1.70 persen, ACES sebesar 8.78 persen, MEDC sebesar 2.96 persen, ITMG sebesar 3.04 persen, UNTR sebesar 3.10 persen, TINS sebesar 1.22 persen, BDMN sebesar 4.94 persen, JPFA sebesar 2.31 persen, BBCA sebesar 22.79 persen, BJBR sebesar 0.57 
persen, PNBN sebesar 0.84 persen, TARA sebesar 0.41 persen, PBRX sebesar 0.07 persen, dan ANTM sebesar 0.01 persen.

Saham-saham yang dapat membentuk kombinasi portofolio optimal berdasarkan model indeks tunggal pada saham-saham Indeks Kompas 100 Periode Agustus 2016-Januari 2019 sebanyak 20 saham, yaitu saham Bumi Resources Tbk. (BUMI), Mitra Adiperkasa Tbk. (MAPI), Vale Indonesia Tbk. (INCO), Delta Dunia Makmur Tbk. (DOID), Indika Energy Tbk. (INDY), Charoen Pokphand Indonesia Tbk. (CPIN), Sentul City Tbk. (BKSL), Ace Hardware Indonesia Tbk. (ACES), Medco Energi Internasional Tbk. (MEDC), Indo Tambangraya Megah Tbk. (ITMG), United Tractors Tbk. (UNTR), Timah (Persero) Tbk. (TINS), Bank Danamon Indonesia Tbk. (BDMN), Japfa Comfeed Indonesia Tbk. (JPFA), Bank Central Asia Tbk. (BBCA), Bank Pembangunan Jawa Barat Dan Banten Tbk. (BJBR), Bank Pan Indonesia Tbk. (PNBN), Sitara Propertindo Tbk. (TARA), Pan Brothers Tbk. (PBRX), Aneka Tambang (Persero) Tbk. (ANTM).

Bagi Investor yang ingin berinvestasi tapi ingin mendapatkan risiko yang kecil dengan menggunakan saham-saham dalam Indeks Kompas 100, investor dapat melakukan investasi dengan cara membentuk sebuah portofolio dan menginvestasikan dananya sesuai dengan proporsi dana yang terbentuk dari penelitian, dimana saham ACES diproporsikan dananya sebesar BUMI sebesar 2.55 persen, MAPI sebesar 21.40 persen, INCO sebesar 4.07 persen, DOID sebesar 3.47 persen, INDY sebesar 5.89 persen, CPIN sebesar 9.90 persen, BKSL sebesar 1.70 persen, ACES sebesar 8.78 persen, MEDC sebesar 2.96 persen, ITMG sebesar 3.04 persen, UNTR sebesar 3.10 persen, TINS sebesar 1.22 persen, BDMN sebesar 4.94 persen, JPFA sebesar 2.31 persen, BBCA sebesar 22.79 persen, BJBR sebesar 0.57 persen, PNBN sebesar 0.84 persen, TARA sebesar 0.41 persen, PBRX sebesar 0.07 persen, dan ANTM sebesar 0.01 persen.. Portofolio optimal ini juga memberikan keuntungan tingkat pengembalian dimasa datang (expected return) sebesar 3.20 persen, dan dengan risiko portofolio yang kecil yaitu sebesar 0,11 persen.

Bagi peneliti selanjutnya, disarankan menggunakan pendekatan Markowits dan berbagai indeks lainnya ataupun berbagai sektor yang ada di Bursa Efek Indonesia (BEI) dalam pembentukan portofolio optimalnya dan juga mampu untuk memberikan perbandingan indeks atau sektor mana saja yang memberikan tingkat return dan risiko yang terbaik

\section{REFERENSI}

Abramov, A., Radygin, A., \& Chernova, M. (2015). Long-term portfolio investment: New insight into return and risk. Voprosy Ekonomiki, 2015(10), 54-77. https://doi.org/10.32609/0042-8736-2015-10-54-77

Agmiviolya, Y. C., Dzulkirom, M., \& Hidayat, R. R. (2014). Analisis Portofolio dengan Single Index Model dalam Upaya Meminimalisir Risiko Investasi Pasar Modal (Studi Pada Perusahaan Sektor Food and Beverages yang Listing di Bursa Efek Indonesia Periode 2011-2013. Jurnal Administrasi Bisnis 
(JAB), 13(1), 1-8.

Ariasih, N. L. P. I., \& Mustanda, I. K. (2018). Pembentukan Portofolio Optimal Menggunakan Model Indeks Tunggal Pada Saham Indeks LQ45. E-Journal Manajemen Unud, 7(8), 4508-4538.

Arisandy, F. N., Elly, M. I., \& Hudzafidah, K. (2017). Analisis Penentuan Saham Portofolio Optimal Dengan Model Indeks Tunggal Dalam Perusahaan Yang Tergabung Indeks Kompas 100 Pada Bursa Efek Indonesia Periode 20132015 Studi Untuk Perusahaan Perbankan. Jurnal Ecobuss, 5(1), 1-12.

Bosch-Badia, M. T., Montllor-Serrats, J., \& Tarrazon-Rodon, M. A. (2018). Sustainability and ethics in the process of price determination in financial markets: A conceptual analysis. Sustainability (Switzerland), 10(5), 1-24. https://doi.org/10.3390/su10051638

Chintan, A. S. (2015). Construction of Optimal Portfolio Using Sharpe Index Model \& Camp for BSE Top 15 Securities. International Journal of Research and Analytical Reviews, 2(2), 1269-2348.

Darmawan, I. P. P. A., \& Purnawati, N. K. (2015). Pembentukan Portofolio Optimal Pada Saham-Saham Diindeks LQ 45 Dengan Menggunakan Model Indeks Tunggal. E-Jurnal Manajemen Unud, 4(12), 4335-4361.

Darmitha, S., \& Purbawangsa, I. . A. (2016). Study Komparatif Kinerja Portofolio Optimal Saham LQ45 Dan 50 Most Active Stocks By Trading Frequency. EJournal Manajemen Unud, 5(11), 7185-7213.

Farias, C. A., Vieira, W. da C., \& Santos, M. L. dos. (2014). Portofolio Selection Models: Comparative Analysis and Application to the Brazillian Stock Market. Revita De Economic E Agronegocio, 4(3), 387-408.

Giri, L. K., \& Parhi, G. (2017). Optimum Portfolio Construction Using Single Index Model. Intercontinental Journal Of Finance Research Review, 5(2), 23471654.

Gopalakrishnan, M. M. (2014). Optimal Portofolio Selection Using Sharpe's Single Index Model. Indian Journal Of Applied Research, 4(1), 286-288.

Hamdani, A. S., \& Muhardi, W. R. (2015). Pembentukan Portofolio Optimal Pada Indeks Kompas 100 Periode 2013-2014. Jurnal Ilmiah Mahasiswa Universitas Surabaya, 4(2), 1-13.

Harun, Y. S., Safitri, E., \& Wijaya, T. (2015). Analisis Portofolio yang Optimal pada Saham Indeks Kompas100 di Bursa Efek Indonesia. Jurnal Jurusan Manajemen STIE MDP, 1(1), 1-12. 
Kozłowska, M. (2015). Problems Connected with Measuring Risks of Foreign Direct Investments. Journal of Economics and Management, 20(20), 93-105.

Lerskullawat, A. (2017). Effects of banking sector and capital market development on the bank lending channel of monetary policy: An ASEAN country case study. Kasetsart Journal of Social Sciences, 38(1), 9-17. https://doi.org/10.1016/j.kjss.2016.10.001

Lestari, D. P., \& Candraningrat, I. R. (2014). Studi Komparatif Portofolio Optimal Menggunakan Proksi LQ 45 Dan IHSG Melalui Pendekatan Model Indeks Tunggal. E-Journal Manajemen Unud, 3(3), 578-594.

Mandal, N. (2014). Sharpe's Single Index Model and Its Application to Construct Optimal Portofolio: An Empirical Study. Yale - Great Lakes Institute of Management, 7(1), 1-21.

Mary, J. F., \& Rathika, G. (2015). The Single Index Model and The Construction of Optimal Portofolio With Cnxpharma Scrip. Journal Impact Factor, 6(1), 87-96.

Masry, M. (2017). The Impact of Technical Analysis on Stock Returns in an Emerging Capital Markets (ECM's) Country: Theoretical and Empirical Study. International Journal of Economics and Finance, 9(3), 91. https://doi.org/10.5539/ijef.v9n3p91

Meman, M. U. (2015). Optimal Equity Portfolio Construction by using Sharpe Single Index Model with reference to the BSE-30 (Bombay Stock Exchange) Securities. Global Journal For Research Analysis, 4(12), 2277-8160.

Qur'anitasari, R. R. H., \& Sulasmiyati, S. (2016). Analisis Pembentukan Portofolio Optimal Dalam Meminalkan Tingkat Risiko Investasi Dengan Menggunakan Model Indeks Tunggal (Studi Kasus Saham LQ-45 Di Bursa Efek Indonesia Periode Januari 2013-Juli 2015). Jurnal Administrasi Bisnis, 21(1), 140-149.

Rahmadin, R., Topowijono, \& Zahroh, Z. . (2014). Pembentukan Portofolio Optimal Saham Berdasarkan Model Indeks Tunggal (Studi pada Saham Indeks LQ-45 di BEI Tahun 2011-2013). Jurnal Administrasi Bisnis, 9(2), 129.

Ramadhan, D. R., Handayani, S. R., \& Endang, M. G. wi. (2014). Analisis Pemilihan Portofolio Optimal dengan Model dan Pengembangan dari Portofolio Markowitz (Studi Pada Indeks Bisnis 27 di Bursa Efek Indonesia Periode 2011 - 2013). Jurnal Administrasi Bisnis, 14(1), 1-10.

Sanrego, Y. D. (2017). the Role of Islamic Capital Market for Micro, Small, and 
Medium Enterprises (Msmes) Through Synergy of Mutual Fund and Venture Capital Institution. Journal of Islamic Monetary Economics and Finance, 3(1), 81-112. https://doi.org/10.21098/jimf.v3i1.711

Setyoningsih, A. T., Suhadak, \& Topowijono. (2015). Analisis Portofolio Optimal Dengan Single Index Model Untuk Meminimumkan Risiko Bagi Investor Di Bursa Efek Indonesia (Studi Pada Saham Indeks Kompas 100 Periode Februari 2010-Juli 2014). Jurnal Administrasi Bisnis (JAB), 23(1), 1-9.

Sushko, V., \& Turner, G. (2018). The Implications of Passive Investing for Securities Markets. BIS Quarterly Review, 1(1), 113-131. Retrieved from https://www.bis.org/publ/qtrpdf/r_qt1803j.pdf

Utamayasa, K. N., \& Wiagustini, N. L. P. (2016). Penentuan Portofolio Optimal Dengan Menggunakan Model Indeks Tunggal Pada Saham Perbankan Di Bursa Efek Indonesia. E-Journal Manajemen Unud, 5(6), 3905-3933.

Widyasari, A. W. P. (2017). Penggunaan Model Indeks Tunggal Dalam Menilai Resiko Dan Return Saham Untuk Pilihan Berinvestasi. Jurnal Akuntansi, Prodi. Akuntansi - FEB, Unipma, 1(1), 1-12.

Yin, D. (2019). Investment Decision Based on Entropy Theory. Modern Economy, 10(04), 1211-1228. https://doi.org/10.4236/me.2019.104083 